\section{Explaining outputs of primary health care: population and practice factors}

\author{
Deborah Baker, Rudolf Klein
}

\begin{abstract}
Objective-To examine whether variations in the activities of general practice among family health service authorities can be explained by the populations characteristics and the organisation and resourcing of general practice.

Design-The family health services authorities were treated as discrete primary health care systems. Nineteen performance indicators reflecting the size, distribution, and characteristics of the population served; the organisation of general practice (inputs); and the activities generated by general practitioners and their staff (output) were analysed by stepwise regression.
\end{abstract}

Setting-90 family health services authorities in

Main outcome measures-Rates of cervical smear testing, immunisation, prescribing, and night

Results $-53 \%$ of the variation in uptake of cervical cytology was accounted for by Jarman score ( $t=$ $-3.3)$, list inflation ( -0.41$)$, the proportion of practitioners over $65(-0.64)$, the number of ancillary staff per practitioner (2.5), and $70 \%$ of the variation in immunisation rates by standardised mortality ratios $(-6.6)$, the proportion of practitioners aged over $65(-4.8)$, and the number of practice nurses per practitioner (3.5). Standardised mortality ratios (8.4), the number of practitioners (2.3), and the proportion over $65(2.2)$, and the number of ancillary staff per practitioner $(-3 \cdot 1)$ accounted for $69 \%$ of variation in prescribing rates. $54 \%$ of the variation in night visiting was explained by standardised mortality ratios $(7 \cdot 1)$, the proportion of practitioners with lists sizes below $1000(-2 \cdot 2)$, the proportion aged over 65 $(-0.4)$, and the number of practice nurses per practitioner $(-2 \cdot 5)$.

Conclusions-Family health services authorities are appropriate systems for studying output of general practice. Their performance indicators need to be refined and to be linked to other relevant factors, notably the performance of hospital, community, and social services.

\section{Introduction}

A succession of studies have examined the attributes Centre for Analysis of Social Sciences, University of Bath, Bath BA2 7AY Deborah Baker, PHD, research officer

Rudolf Klein, MA, professor of social policy

Correspondence to: $\mathrm{Dr}$ Baker.

BMF 1991;303:225-9 prescribing and night visiting. As such practice activities have achieved much financial and political visibility since the changes introduced by the government's review ${ }^{s}$ and the new contract ${ }^{6}$ it seems important of general practice, showing, for example, the relation between list size and consultation rates. But it has also left much unexplained-for instance, the reasons for the considerable variations in the rates of uptake England. visiting. to ask what factors-apart from the idiosyncrasies of individual practitioners-allow us to explain such variations. Specifically, what are the relative contributions of factors such as the characteristics of the population and the organisation and resourcing of general practice?

In our inquiry we shifted the focus of attention from individual general practitioners to the primary health care systems in which they work. In effect there are $\mathbf{9 0}$ such health care systems in England: the $\mathbf{9 0}$ family health services authorities responsible for the administration of general practice and other primary health care services. The authorities operate within the same legislative and financial framework and administer the same national contract, but they differ in several respects. Firstly, they vary in the size, distribution, and characteristics of the population served: the environmental setting for general practice. Secondly, they vary in terms of the inputs into general practiceits organisation and the resources available. Thirdly they vary in the activities of the general practitioners and their staff-the outputs of the system. We explored how far variations in rates of uptake of cervical cytology and immunisation and rates of prescribing and night visiting can be explained by variations in population characteristics and practice inputs and tried to identify which factors are important.

\section{Methods}

The data were drawn from the 1987-8 set of family practitioner committee indicators, as revised at 30 September 1989, produced by the Department of Health. The family practitioner committee indicators are, in effect, a compilation of the statistics routinely collected by the department about the populations being served. In this respect they are similar to the performance indicators set for the hospital and community services. These statistics or performance indicators are used by the department (and by regional health authorities) to monitor the management and activities of the services concerned. Collection of data has been introduced largely because of parliamentary pressure for more effective central government control and accountability. ${ }^{7}$ The family practitioner committees have now been converted into family health services authorities, so to avoid confusion we shall refer to family health services authority (rather than family practitioner committee) indicators in what follows.

The advantage of using the family health service authority.indicators is that they usefully bring together the data regularly collected by the Department of Health. But the department's decision about what information is worth collecting inevitably reflects its own financial and managerial interests. The information excludes many factors that might be relevant for a full understanding of the dynamics of primary health care. The information about all three sets of 
factors-population, practice inputs, and practice outputs -is incomplete: our choice of variables for analysis was therefore constrained. In addition the indicators contain no data about the outcome of general practice - that is, its impact on the health of the population. This is unfortunate but understandable: it is difficult to isolate the contribution of primary health care to the health of a population, given all the other factors involved.

After excluding the data exclusively on ophthalmic, pharmaceutical, and dental services, we were left with 36 variables relevant to general practice. We chose 19 of these for use in the analysis. We used two criteria in selecting the variables: the variables should fit into one of our three analytical categories and it should be possible to generate some hypotheses about their possible relation to other factors. Table I shows the complete list.

\section{POPULATION VARIABLES}

These fell into two groups. The first group contained population indicators that are conventionally assumed to be linked to demands on the health care system: standardised mortality ratios for the population aged under 65 , perinatal mortality, and the Jarman underprivileged area score. The first two have consistently picked up class and geographic differences in health status ${ }^{8} ;$ standardised mortality ratios, are often used as a proxy for morbidity, as in the Resource Allocation Working Party (RAWP) formula, and are strongly correlated with various indicators of social deprivation The Jarman index is based on factors identified by general practitioners as indicators of demand ${ }^{9}$ and is used to determine eligibility for deprivation area payments; a positive value indicates that an area has high deprivation. The method used to create the index has been criticised, and the index could arguably be described more accurately as a measure of workload than of social deprivation. ${ }^{10-13}$ It does however, include aspects of the social environment not fully captured by either standardised mortality ratios or perinatal

TABLE I-Descriptive characteristics of selected family health services authority performance indicators

\begin{tabular}{|c|c|c|c|c|}
\hline & $\begin{array}{c}\text { No of } \\
\text { observations }\end{array}$ & Minimum value & Maximum value & $\begin{array}{c}\text { Mean (SD) or } \\
\text { median (interquartile range) }\end{array}$ \\
\hline \multicolumn{5}{|l|}{ Population characteristics: } \\
\hline $\begin{array}{l}\text { Standardised mortality ratios } \\
(\text { population aged }<65)\end{array}$ & $90 \cdot 00$ & $72 \cdot 91$ & $135 \cdot 60$ & $102 \cdot 26(14 \cdot 20)$ \\
\hline $\begin{array}{l}\text { Jarman underprivileged } \\
\text { area score }\end{array}$ & 00.00 & -31.06 & 53.34 & $0.27(16.57)$ \\
\hline Perinatal mortality & $90 \cdot 00$ & $\begin{array}{r}-31.00 \\
4.56\end{array}$ & $\begin{array}{l}33.34 \\
14 \cdot 60\end{array}$ & $\begin{array}{l}0.27(10.51) \\
8.85(1.79)\end{array}$ \\
\hline List inflation ${ }^{\star}$ & $90 \cdot 00$ & $-1 \cdot 39$ & $34 \cdot 41$ & $4 \cdot 15(2 \cdot 32$ to $6 \cdot 61)$ \\
\hline $\begin{array}{l}\text { Administrative costs of } \\
\text { authority (£000s/10 } 000 \\
\text { population) }\end{array}$ & $90 \cdot 00$ & $6 \cdot 37$ & $33 \cdot 60$ & $9.74(8.50$ to $12 \cdot 23)$ \\
\hline $\begin{array}{l}\text { Registration transactions as \% } \\
\text { of registered population }\end{array}$ & $90 \cdot 00$ & $15 \cdot 21$ & $101 \cdot 04$ & $28 \cdot 10(24 \cdot 37$ to $31 \cdot 64)$ \\
\hline \multicolumn{5}{|l|}{ Practice organisation: } \\
\hline $\begin{array}{l}\text { No of practitioners } 10000 \\
\text { patients on their lists }\end{array}$ & $90 \cdot 00$ & $4 \cdot 34$ & $5 \cdot 58$ & $4.95(0.26)$ \\
\hline Turnover of practitioners & $90 \cdot 00$ & 0.03 & $0 \cdot 19$ & $0.12(0.03)$ \\
\hline $\begin{array}{l}\% \text { Of practitioners with list } \\
\text { size }<1000^{\star}\end{array}$ & $90 \cdot 00$ & 0.00 & $10 \cdot 53$ & $1.49(0.72$ to 2.37$)$ \\
\hline $\begin{array}{l}\% \text { Of practitioners with list } \\
\text { size }>2500^{\star}\end{array}$ & $90 \cdot 00$ & $0 \cdot 00$ & $35 \cdot 71$ & $12 \cdot 26(7 \cdot 37$ to $19 \cdot 65)$ \\
\hline $\begin{array}{l}\% \text { Of practitioners aged } \\
\text { under } 65 \text { in singlehanded } \\
\text { practices }^{\star}\end{array}$ & $90 \cdot 00$ & $1 \cdot 72$ & $23 \cdot 88$ & $8 \cdot 31(4.53$ to $12 \cdot 56)$ \\
\hline $\begin{array}{l}\% \text { Of practitioners aged } \geqslant 65^{\star} \\
\text { Work time equivalent ancillary }\end{array}$ & $90 \cdot 00$ & $0 \cdot 00$ & $20 \cdot 57$ & $3 \cdot 15(2 \cdot 15$ to $6 \cdot 52)$ \\
\hline staff/practitioner & $90 \cdot 00$ & 0.75 & 1.67 & $1 \cdot 25(0 \cdot 18)$ \\
\hline $\begin{array}{l}\text { Practice nurses/practitioner } \\
\% \text { Practitioners having consent }\end{array}$ & $90 \cdot 00$ & 0.01 & $0 \cdot 27$ & $0 \cdot 11(0.06)$ \\
\hline $\begin{array}{l}\text { \% Practitioners having consent } \\
\text { to use deputising services } \\
\text { Practice activity: }\end{array}$ & $89 \cdot 00$ & $0 \cdot 00$ & $100 \cdot 00$ & $54 \cdot 80(38 \cdot 40)$ \\
\hline Prescriptions $/ 10000$ & & & & \\
\hline $\begin{array}{l}\text { population } \\
\text { Night fees } 10000 \text { registered }\end{array}$ & $90 \cdot 00$ & 57030 & 104004 & $77691(10470)$ \\
\hline $\begin{array}{l}\text { Night fees } / 10000 \text { registered } \\
\text { population } \\
\text { Fees for immunisation } / 10000\end{array}$ & $90 \cdot 00$ & 0.98 & 4.97 & $2 \cdot 84(0 \cdot 72)$ \\
\hline $\begin{array}{l}\text { registered population } \\
(1987-8)\end{array}$ & $90 \cdot 00$ & $1 \cdot 37$ & $7 \cdot 01$ & $4 \cdot 16(1 \cdot 42)$ \\
\hline $\begin{array}{l}\text { Fees for cervical cytology/ } \\
10000 \text { women aged } 35-64\end{array}$ & $90 \cdot 00$ & $2 \cdot 86$ & $12 \cdot 10$ & $7.92(1.97)$ \\
\hline
\end{tabular}

*Variables are not normally distributed. In these cases means and standard deviations have been substituted by medians and interquartile range. mortality. It is a summation of eight variables: the proportions of elderly people living on their own, children aged under 5 , lone parents, unskilled workers, unemployed, overcrowded households, people changing their address, and ethnic minorities.

The second group comprised three closely related variables that, in different ways, might be expected to measure social stability: list inflation, administrative costs of the family health services authority per 10000 population, and registration transactions as a percentage of the population. List inflation reflects the percentage of the population actually registered with general practitioners (population data from Office of Population Censuses and Surveys); the lower the list inflation, the higher the proportion of the population registered and the greater the likelihood of its stability. The inclusion of all three measures reflects our uncertainty about which was the best proxy for measuring population mobility and the accompanying problems for primary health care.

\section{INPUT VARIABLES}

Input variables also fell into two groups: those measuring the quantity and type of resources and those providing some indication of the way in which general practice is organised. The first included the ratio of general practitioners to the population and the ratio of practice nurses and ancillaries to general practitioners. The second included the percentage of practitioners with lists below 1000 or above 2500 , who were aged over 65 , or who were under 65 but had a singlehanded practice. The indicators are clearly incomplete. On the resources side it would be important to supplement family health services authority data with those from the district health authority: the performance of the primary health care system will inevitably be affected by the inputs (or lack of them) from the hospital and community services. Here the problem, of course, is that the boundaries of family health services authorities and district health authorities often do not match. On the organisational side it would be desirable to have data on the characteristics of practices, premises, and so on. However, such data will become available as the recommendations of the review group of family health services authority indicators are implemented. ${ }^{14}$

\section{OUTPUT VARIABLES}

These measure the activities of general practitioners. They included outputs where the aim of public policy, as reflected in the new contract, is to maximise activity: uptake of cervical screening and immunisation (for cervical screening fees are an accurate enough proxy for activity) and outputs where the quantity does not necessarily tell us anything about the adequacy or otherwise of those activities: the number of prescriptions issued and the number of night visits made per 10000 population (for which fees are a good proxy for activity). Again more information would be desirable - for example, a more complete picture would have been obtained if data on consulting rates, the use of diagnostic facilities, and referral rates had been available.

The aim of our analysis was to identify the combination of population and input variables that best explained variation in outputs. Initially, each group of indicators was subject to intercategory and intracategory correlation. Matrices arising from these analyses were explored for significant association between variables. This provided a preliminary insight into the relation between the indicators and we were also able to eliminate those that were clearly and consistently unrelated. Next, we used multiple regression to establish a sounder statistical basis for interpreting these data. Stepwise regression formed the basis of this investigation. ${ }^{\text {is }}$ Each output indicator 
was regressed initially against indicators in the other two categories. In the context of these analyses, the procedure systematically discarded the indicators that had no significance - that is, no particularly powerful relation to the output variable under consideration $(t<2 \cdot 0$, where $t$ equals the estimate of the regression coefficient/estimated standard deviation). All data were analysed with INSTAT, a statistical package for the microcomputer, ${ }^{16}$ and for all analyses non-normally distributed variables (see table 1) were normalised by using the natural logarithm.

To interpret the results of these analyses we constructed a "scaffolding" identifying the core components found by multiple regression. This was based on the principle that generally, a desirable multiple regression model is one that accounts for a large proportion of the variation in the variable under consideration, using relatively few predictors whose roles in explaining variation are easily interpreted.$^{15}$ In practice, this meant that we selected only those multiple regression models that accounted for over $50 \%$ of variation in the observed variable $\left(R^{2}>0.50\right)$, and in which this had been achieved with a small number of predictors relative to sample size.

\section{Results}

Table II sets out the results of the multiple regression analyses for the four output variables presented below. Table III summarises the most salient $(r>0.50)$ intracategory and intercategory correlations between environmental, input, and output variables relevant for interpreting the findings.

UPTAKE OF CERVICAL CYTOLOGY (WOMEN AGED 35-64)

Higher rates of uptake of cervical cytology were associated with lower scores on the Jarman underprivileged area index, lower list inflation, a smaller number of general practitioners over 65 , and more ancillary staff per practice. These four factors explained $53 \%$ of the variation in uptake of cervical cytology between family health services authorities (table II).

If the Jarman index is taken as a measure of deprivation, it seems that higher uptake of cervical cytology occurred in less deprived areas and in areas with low population mobility. This is unsurprising if we assume that less deprived areas are likely to be more stable. But table III suggests that the effects of these two factors may be independent: there was no strong correlation between list inflation and Jarman scores. The proportion of general practitioners over 65 was correlated with both list inflation $(r=0.71)$ and Jarman scores $(r=0.56)$, suggesting that areas with less deprivation and those with greater population stability both have a smaller percentage of general practitioners over 65 .

Interestingly, it was the number of ancillary staff per general practitioner and not the number of practice nurses that had more explanatory power. This may be because there were more ancillaries per practice in areas where there were fewer general practitioners over $65(r=-0 \cdot 50)$. Alternatively it may indicate that administration of the process of call-recall is the key to ensuring high rates of uptake for cervical cytology.

\section{IMMUNISATION RATES}

High rates of immunisation were associated with lower standardised mortality ratios (for the under $65 \mathrm{~s}$ ), a smaller percentage of general practitioners over 65 , and more practice nurses per general practitioner. These three factors explained $70 \%$ of the variation (table II). Intercategory correlations (table III) indicated that where standardised mortality ratios were lower, the number of practice nurses per practice was higher $(r=-0.53)$, but there was no strong correlation between either of these variables and the number of general practitioners over 65 . So immunisation rates were higher in healthier areas, which tended to have practices with more practice nurses; they were also higher in areas with fewer older general practitioners.

\section{RATES OF PRESCRIBING PER 10000 POPULATION}

Lower rates of prescribing per 10000 population were associated with lower standardised mortality ratios, fewer general practitioners per 10000 patients on lists, a smaller proportion of general practitioners over 65 , and a larger number of ancillary workers per general practitioner. These four factors accounted for $69 \%$ of variation (table II).

Healthier areas might be expected to have lower prescribing rates, and these are also strongly associated with better staffed practices. But this does not mean that lower prescribing can always be interpreted as a positive indicator as such rates are also associated with fewer practitioners per patient.

\section{NIGHT VISITING}

Lower levels of night visiting were related to lower standardised mortality ratios, practices with more nurses per general practitioner, practices with a greater proportion of general practitioners over 65 , and practices with small list sizes. There were thus two contrary trends combining to explain variation in night visiting. Lower rates were associated with healthier areas and, in turn, the lower the standardised mortality ratios, the more practice nurses per practice $(r=0.53)$. However, lower rates were also associated with certain types of practice found in areas characterised by a

TABLE II-Multiple regression analyses showing significant relation between practice outputs and other family health services authority performance indicators

\begin{tabular}{|c|c|c|c|c|c|c|c|c|c|c|c|c|}
\hline \multirow[b]{2}{*}{ Variables in Regression } & \multicolumn{3}{|c|}{ Fees for cervical cytology } & \multicolumn{3}{|c|}{ Fees for immunisations } & \multicolumn{3}{|c|}{$\begin{array}{l}\text { Prescriptions } / 10000 \\
\text { population }\end{array}$} & \multicolumn{3}{|c|}{ Night visiting fees } \\
\hline & $\begin{array}{l}\text { Standard } \\
\text { regression } \\
\text { coefficient }\end{array}$ & $\mathrm{t}$ & $\mathrm{p}$ Value & $\begin{array}{l}\text { Standard } \\
\text { regression } \\
\text { coefficient }\end{array}$ & $\mathrm{t}$ & $\mathrm{p}$ Value & $\begin{array}{l}\text { Standard } \\
\text { regression } \\
\text { coefficient }\end{array}$ & $t$ & $\mathrm{p}$ Value & $\begin{array}{l}\text { Standard } \\
\text { regression } \\
\text { coefficient }\end{array}$ & $t$ & $\mathrm{p}$ Value \\
\hline $\begin{array}{l}\text { Standardised mortality ratio } \\
\text { (population aged }<65 \text { ) } \\
\text { Jarman underprivileged area }\end{array}$ & & & & $-0 \cdot 04$ & $-6 \cdot 6$ & $<0.001$ & 486 & $8 \cdot 4$ & $<0.001$ & 0.04 & $7 \cdot 1$ & $<0.001$ \\
\hline $\begin{array}{l}\text { score } \\
\text { List inflation }\end{array}$ & $\begin{array}{l}-0.03 \\
-0.41\end{array}$ & $\begin{array}{l}-3 \cdot 3 \\
-2 \cdot 2\end{array}$ & $\begin{array}{l}<0.01 \\
<0.05\end{array}$ & & & & & & & & & \\
\hline $\begin{array}{l}\text { No of practitioners } / 10000 \\
\text { patients on lists } \\
\% \text { Of practitioners with list }\end{array}$ & & & & & & & 8113 & $2 \cdot 3$ & $<0.05$ & & & \\
\hline $\begin{array}{l}\text { sizes }<1000 \\
\% \text { Of practitioners aged } \geqslant 65 \\
\text { Work time equivalent ancillary }\end{array}$ & -0.64 & $-2 \cdot 3$ & $<0.05$ & $-0 \cdot 12$ & $-4 \cdot 8$ & $<0.001$ & 10719 & $2 \cdot 2$ & $<0.05$ & $\begin{array}{l}-0 \cdot 2 \\
-0 \cdot 4\end{array}$ & $\begin{array}{l}-2 \cdot 2 \\
-3 \cdot 6\end{array}$ & $\begin{array}{l}<0.05 \\
<0.01\end{array}$ \\
\hline $\begin{array}{l}\text { staff/practitioner } \\
\text { Practice nurses/practitioner }\end{array}$ & $2 \cdot 5$ & $2 \cdot 5$ & $<0.01$ & $5 \cdot 2$ & 3.5 & $<0.01$ & -48195 & $-3 \cdot 1$ & $<0.01$ & $-2 \cdot 5$ & $-2 \cdot 1$ & $<0.05$ \\
\hline$\%$ Of variance explained $\left(\mathbf{R}^{2}\right)$ & $53 \%$ & & & $70 \%$ & & & $69 \%$ & & & $54 \%$ & & \\
\hline
\end{tabular}

Numbers of observations for each variable $=90$. 


\begin{tabular}{|c|c|c|c|c|c|c|c|c|c|c|c|c|c|c|c|c|}
\hline & $\begin{array}{c}\text { Standardised } \\
\text { mortality } \\
\text { ratios }\end{array}$ & $\begin{array}{c}\text { Jarman } \\
\text { score }\end{array}$ & $\begin{array}{c}\text { List } \\
\text { inflation* }\end{array}$ & $\begin{array}{c}\text { Authority } \\
\text { administrative } \\
\text { costs/10000 } \\
\text { population } \\
\end{array}$ & $\begin{array}{c}\text { No of } \\
\text { practitioners/ } \\
10000 \\
\text { patients } \\
\end{array}$ & $\begin{array}{c}\% \text { Of } \\
\text { practitioners } \\
\text { with list sise } \\
<1000^{\star} \\
\end{array}$ & $\begin{array}{c}\% \text { Of } \\
\text { practitioners } \\
\text { with list size } \\
>2500^{*}\end{array}$ & $\begin{array}{c}\% \text { Of } \\
\text { practitioners } \\
<65 \text { in single } \\
\text { handed practice }\end{array}$ & $\begin{array}{c}\% \text { Of } \\
\text { practitioners } \\
\text { aged } \geqslant 65^{\star}\end{array}$ & $\begin{array}{l}\text { Work time } \\
\text { equivalent } \\
\text { ancillaries/ } \\
\text { practitioner }\end{array}$ & $\begin{array}{c}\text { Practice } \\
\text { nurses/ } \\
\text { practitioner }\end{array}$ & $\begin{array}{c}\% \text { With } \\
\text { consent } \\
\text { to use } \\
\text { deputies }\end{array}$ & $\begin{array}{c}\text { Prescriptions/ } \\
1000 \\
\text { population } \\
\end{array}$ & $\begin{array}{c}\text { Night fees } \\
10000 \\
\text { registered } \\
\text { population } \\
\end{array}$ & $\begin{array}{l}\text { Immunisation } \\
\text { fees } 10000 \\
\text { registered } \\
\text { population } \\
\end{array}$ & $\begin{array}{c}\text { Fees for } \\
\text { cervical } \\
\text { cytology/ } \\
10000 \text { women } \\
\text { aged } 35-64 \\
\end{array}$ \\
\hline $\begin{array}{l}\text { Standardised } \\
\text { mortality ratios }\end{array}$ & 1.00 & 0.74 & & & & & & & & & -0.53 & 0.5 & 0.77 & 0.6 & -0.73 & \\
\hline $\begin{array}{l}\text { Jarman score } \\
\text { List inflation } \\
\text { Authority } \\
\text { administrative } \\
\text { costs } / 10000\end{array}$ & 0.74 & 1.00 & $1 \cdot 00$ & 0.79 & & & & & $\begin{array}{l}0.56 \\
0.71\end{array}$ & & & & & & -0.56 & $\begin{array}{l}-0.56 \\
-0.53\end{array}$ \\
\hline $\begin{array}{l}\text { population } \\
\text { No of practitioners/ }\end{array}$ & & & 0.79 & 1.00 & & 0.55 & & 0.5 & 0.73 & & & & & & & -0.58 \\
\hline $\begin{array}{l}10000 \text { patients } \\
\% \text { Of practitioners } \\
\text { with list size }\end{array}$ & & & & & 1.00 & & -0.84 & & & & & & & & & \\
\hline$<1000^{\star}$ & & & & 0.55 & & $1 \cdot 00$ & & 0.61 & $0 \cdot 6$ & & & 0.55 & & & & \\
\hline $\begin{array}{l}\% \text { Of practitioners } \\
\text { with list size }\end{array}$ & & & & & & & & & & & & & & & & \\
\hline $\begin{array}{l}>2500^{*} \\
\% \text { Of practitioners } \\
\text { aged }<65 \text { in } \\
\text { singlehanded }\end{array}$ & & & & & -0.84 & & 1.00 & 0.57 & & -0.6 & & & & & & -0.51 \\
\hline $\begin{array}{l}\text { practice } \\
\% \text { Of practitioners }\end{array}$ & & & & 0.5 & & 0.61 & 0.57 & 1.00 & 0.53 & -0.53 & & & & & & -0.45 \\
\hline $\begin{array}{l}\text { aged } \geqslant 65^{\star} \\
\text { Work time equivalent } \\
\text { ancillaries } /\end{array}$ & & 0.56 & 0.71 & 0.73 & & 0.6 & & 0.53 & 1.00 & -0.5 & & 0.53 & & & -0.56 & -0.65 \\
\hline $\begin{array}{l}\text { practitioners } \\
\text { Practice nurses }\end{array}$ & & & & & & & -0.6 & -0.53 & $-0 \cdot 5$ & 1.00 & & -0.53 & & & & 0.55 \\
\hline $\begin{array}{l}\text { practitioners } \\
\% \text { With consent to }\end{array}$ & -0.53 & & & & & & & & & & 1.00 & -0.57 & -0.5 & & 0.63 & \\
\hline $\begin{array}{l}\text { use deputies } \\
\text { Prescriptions/ }\end{array}$ & 0.5 & & & & & & 0.55 & & 0.53 & -0.53 & -0.57 & 1.00 & & & -0.66 & \\
\hline $\begin{array}{l}10000 \text { population } \\
\text { Night fees/10 } 000 \\
\text { registered }\end{array}$ & 0.77 & & & & - & & & & & & -0.5 & & 1.00 & 0.67 & -0.58 & \\
\hline $\begin{array}{l}\text { population } \\
\text { Immunisation fees } \\
10000 \text { registered }\end{array}$ & 0.6 & & & & & & & & & & & & 0.67 & 1.00 & & \\
\hline $\begin{array}{l}\text { population } \\
\text { Fees for cervical } \\
\text { cytology } / 10000\end{array}$ & -0.73 & -0.56 & & & & & -0.51 & & -0.56 & & 0.63 & -0.66 & -0.58 & & 1.00 & 0.56 \\
\hline women aged 35-64 & & -0.56 & -0.53 & -0.58 & & & -0.51 & & -0.65 & 0.55 & & & & & 0.56 & 1.00 \\
\hline
\end{tabular}

${ }^{\star}$ Data non-normally distributed. Loge values used to calculate correlation.

greater percentage of general practitioners over 65, which in turn were associated with more list sizes under $1000(r=0 \cdot 6)$.

\section{Discussion}

The population characteristics and the inputs into the primary health care system selected for this analysis combined to explain a high percentage of variation in outputs between family health services authorities. The percentage of variation explained was in fact higher than is usual in this kind of exercise, ${ }^{17}$ ranging from $53 \%$ for uptake of cervical cytology to $70 \%$ for immunisation rates. Standardised mortality ratio was the most consistently important population factor, appearing in three of the four equations. In contrast, the Jarman score, though highly correlated with standardised mortality ratios $(r=0.74)$, appeared in only one equation, as did list inflation.

Though our results show that population characteristics account for some of the variation in outputs, the measures were not specific enough to draw firm conclusions about the exact nature of this relation. For instance, standardised mortality ratios, though often used as a proxy for the health consequences of deprivation, measure the mortality of only the employed population under 65 and exclude vulnerable groups such as the unemployed, elderly people living alone, and single parents most likely to make the heaviest demands on the primary health care system. ${ }^{18}$ The Jarman index, on the other hand, does attempt, albeit indirectly, to assess the extent of such vulnerable groups in an area. The heterogeneity of the indicators, however, gives the index limited power in explaining outputs. There is no reason for thinking that the proportion of elderly people living on their own will be linked to immunisation rates, while the proportion of single parents may well be inversely related to uptake. Disaggregating the Jarman index into its component parts may, and indeed does, yield indicators better fitted to explain outputs: unemployment rates and the proportion of elderly people living alone seem to be particularly important in this regard ( $\mathrm{R}$ F Carter, personal communication).

Our findings also underline the fact that the way in which general practice is organised and resourced influences outputs and that this influence is independent of population characteristics. In this respect the findings lend strong support to policies designed to maximise the use of preventive health services by encouraging the employment of ancillaries and practice nurses and by discouraging general practitioners from working after the age of 65 .

The relation between population and practice characteristics and their interaction in explaining outputs still remains elusive. For example, the proportion of general practitioners over 65 may have emerged as a significant factor because it sums up the cumulative effect of a number of related variables. A high proportion of general practitioners over 65 seems to be related to family health services authorities serving populations with high social deprivation, as measured on the Jarman index, and that are mobile, as measured by list inflation and administrative costs; it is also related to high proportion of singlehanded general practitioners under 65 and to more use of deputising services. We may therefore be tapping an inner city practice syndrome, where there is an asymmetrical relation between need as measured by the population characteristics and inputs as measured by various practice characteristics. But we cannot be sure. The inclusion of additional input variables, such as the percentage of teaching practices, could throw further light on this.

As already noted, the outputs fall into two groups. For uptake of cervical cytology and immunisation there is no ambiguity: high output an be equated with desired output. For rates of prescription and night visiting, however, it is not clear what the rates mean in terms of appropriateness of practice. Lower rates of prescribing were associated with lower standardised mortality ratios but with fewer practitioners per patient. Lower rates of night visiting were similarly associated with lower standardised mortality ratios but 
also with more general practitioners over 65 and smaller list sizes. In these circumstances, low rates indicate both a healthier population and a less adequate practice organisation. Why and where such population and practice characteristics coincide to explain these outputs requires further research.

Our analysis is inevitably a tentative first step. It identifies the need for further development. Not only is there a case for developing a more sophisticated data set for primary health care, along the lines recommended by the Family Practice Service Indicators Working Party, ${ }^{14}$ and breaking down composite indicators such as the Jarman index into their component parts, but there is a need to develop outcome indicators designed to measure the impact of primary health care on the populations's health and to link family health service authority data with information about hospital, community, and social services. Despite such reservation, the analysis found powerful relations between population, input, and output variables with relatively simple techniques. We conclude therefore that treating family health services authorities as discrete primary health care systems and using the family health service authority performance indicators to examine the variations between them is a useful and rewarding basis for studying the dynamics of general practice.

We thank Dr Richard Carter of the Department of Health for guiding us through the family health service authority data set and for help with the manuscript.

1 Butler JR. Hoi munv patients? London: Bedford Square Press, 1980 2 Butler JR, Calman M. Too many patients? Aldershot: Avebury, 1987. Wilkin D, Hallam L, Leavy R, Metcalfe D. Anatomy of urbangeneral practice. London: Tavistock, 1987

4 Bosanquet N, Leese B. Family doctors and incentives. Aldershot: Dartmouth, 1989.

Secretaries of State for Health, Wales, Northern Ireland, and Scotland. Working for patients. London: HMSO, 1989.

6 Department of Health. Terms of service for doctors in general practice. London: Department of Health, 1989.

Klein R, Performance evaluation and the National Health Service, Public Administration 1982:60:385-407.

8 Townsend P, Davidson N, eds. Inequalities in health. Harmondsworth: Penguin, 1988.

9 Jarman B. Underprivileged areas: validation and distribution of scores. $B M \mathcal{J}$ 984;289:1587-92.

10 Carr-Hill RA, Sheldon T. Designing a deprivation payment for general practitioners: the UPA $(8)$ wonderland. $B M J$ 1991;302:393-6.

11 Davey Smith G. Second thoughts on the Jarman Index. BMF 1991;302 Davey Smith
$359-60$.

12 Talbot RJ. Underprivileged areas and health care planning; implications of the use of Jarman indicators of deprivation. BMF 1991;302:383-6.

13 Senior ML. Deprivation payments to general practitioners: not what the doctor ordered. Environment and Planning: C Government and Policy (in press).

14 Review Group of Family Practice Service Indicators. Family practice service indicators London: Department of Health, 1990.

15 Devore J, Peck R. Statistics: the exploration and analysis of data. St Paul, Minnesota: West Publishing Company, 1986.

16 Statistical Services Centre. Instat: an interactive statistics package. Reading, University of Reading, 1986

17 Mechanic D. Correlates of physician utilization: why do major multivariate studies of physician utilization find trivial psychosocial and organisational effects? I Health Soc Behav 1979;20:387-96.

18 Illsley R. Occupational class, selection and the production of inequalities in health. Quarterly foumal of Social Affairs 1986;2:151-65.

(Accepted 24 April 199l)

\title{
Admission to child health surveillance lists: the views of FHSA general managers and general practitioners
}

\author{
Alison Evans, Neal Maskrey, Philip Nolan
}

\begin{abstract}
Objectives-To find out the sources of advice that were helpful to managers of family health services authorities in drawing up the criteria for admission of general practitioners to the child health surveillance lists; to determine the criteria used for admission of general practitioners to the family health services authorities' child health surveillance lists; to find out the changes general practitioners have made in child health surveillance in their practices; to determine the experiences of general practitioners relating to admission to the child health surveillance lists and to training in child health surveillance.
\end{abstract}

Design-Survey by postal questionnaire.

Subjects-General managers of all family health services authorities in England and Wales; all general practitioners in Yorkshire and Humberside.

Results-Managers of 80 of 93 family healtin services authorities replied (86\%). A total of $62(78 \%)$ found local community paediatricians helpful in compiling criteria for admission to child health surveillance lists, and $46(57 \%)$ found national guidelines helpful. Fifty seven (71\%) accepted general practitioners who had completed an approved course, and $45(56 \%)$ accepted those with three or more years' experience of child health surveillance. Of the 1966 questionnaires sent to general practitioners, 1233 were satisfactorily completed $(63 \%)$. Of the 919 respondents who had applied to be put on child health surveillance lists, $673(73 \%)$ had been permanently accepted; of these, $441(65 \%)$ had done an approved course and $375(56 \%)$ had had three or more years' experience of child health surveillance. Of the $145(16 \%)$ not accepted, $57(39 \%)$ had done an approved course and $71(49 \%)$ had three or more years' experience. Respondents reported variable quality and availability of courses in child health.

Conclusions - Acceptance of general practitioners on to child surveillance lists has not been carried out consistently despite national guidelines setting out criteria for acceptance.

\section{Introduction}

Before April 1990 general practitioners could provide child health surveillance for their patients but received no extra remuneration for this service. The introduction of a fee for child health surveillance was accompanied by the requirement that family practitioner committees, as they were then, should establish lists of general practitioners eligible to carry out child health surveillance. A Department of Health circular on child health surveillance in regard to implementation of the new GP contract, sent to regional and district general managers in February 1990, emphasised the importance of agreed policies between district health authorities and family practitioner committees so that child health services would be "provided in a consistent and coherent way." The first policy area mentioned by the circular is "the criteria-based on experience and training during the five years immediately preceding the application-which determine the eligibility of general practitioners to be included on the child health surveillance list." The guidelines for the training and accreditation of general practitioners in child health surveillance produced jointly by the Royal College of General Practitioners and the British Paediatric Association are mentioned as an adjunct to this.

These guidelines suggest that there are three groups of general practitioners likely to join the list. The first

BMF 1991;303:229-32 